\title{
An Evolutionary View of the Origins and Functions of Avian Vocal Communication
}

\author{
Eugene S. MORTON* \\ Conservation and Research Center, National Zoological Park, Smithsonian Institution, \\ 1500 Remount Road, Front Royal, VA, 22630, USA
}

Communication is a substitute for fighting in contests over resources. Communication functions to manage the behavior of other animals without risking direct encounters. Females use communication to assess male qualities as mates, thus sexual selection has influenced communication greatly.

The origin of vocal communication is still exhibited in the first land animals, the amphibians. Frogs and toads differ from birds and mammals in that they continue to grow larger after reaching sexual maturity. Larger individuals are able to produce lower pitched calls and they are better fighters than smaller ones. In amphibians, lower pitched calls are both more threatening to other males and attractive to females. Importantly, the physical structure of vocalizations is directly related to the function of these sounds. The relationship between function and a vocalization's physical form is not arbitrary, as is the case with human words.

How is the relation between body size and pitch of calls manifested in birds? The body size/sound pitch relationship is more symbolic and best describes the motivation of the calling bird. Birds use low, harsh, vocalizations when aggressive and high, tonal ones when appeasing or fearful. This relationship is described by the motivation-structural rules model, which relates size symbolism to motivation and is derived from the primitive relation between body size and fighting ability. The motivation-structural rules model is useful in producing hypotheses to test the relation between the physical form of vocalizations and their function.

Vocalizations used for long distance communication, such as most bird song, is a different matter. Here, motivation is usually not as important as sounding close to others. I develop ranging theory to describe how birds assess their distance from one another. The avian ability to resolve very short time intervals between sounds is used to perceive degradation. Degradation is any change in the song as it travels from the singer, such as from reverberation, changes in frequency or amplitude components above those due to spherical spreading of the sound. By comparing a song in their own memory with one that they hear, they are able to judge the distance over which the sound traveled. Ranging theory helps to explain why song learning evolved in some groups as well as the function of dialects, song repertoires, and song complexity.

Key Words: Avian vocal communication, Bioacoustics, Mating systems, Motivation-structural rules, Ranging theory, Whisper song.

When we use communication in diplomacy we replace fighting with communication. Similarly, communication in animals evolved when it could replace fighting. The earliest amphibians probably vocalized and male frogs and toads still use vocalizations

\footnotetext{
*E-mail: emorton@crc.si.edu
} 
to attract mates and repel other males. Anuran vocalizations differ between species to avoid wasting time in mate choice and also differ among individuals within a species, especially in pitch. Smaller toads are intimidated by the deeper sounds larger individuals are able to produce (Davies \& Halliday 1978). Furthermore, females looking for mates are attracted by the deeper calls of larger males (Ryan \& Rand 1993). Thus, some general features of vocal behavior, such as expressing or symbolizing body size, have a long history.

Another fundamental aspect of communication is also found in the first terrestrial animals. The anuran vocalizations that depict size illustrate the crucial role that assessors play in the evolution of communication. Owings \& Morton (1998) describe the ways in which assessors (also termed receivers, reactors, and perceivers) contribute to the evolution and process of communication. They describe communication as interplay between assessors of signals and attempts by senders to manage the behavior of assessors. Communication is not based upon what is conveyed, the focus of informational descriptions but, instead, upon what is accomplished. They call this interplay assessment /management, or $\mathrm{A} / \mathrm{M}$ for short. $\mathrm{A} / \mathrm{M}$ is preferred over informational descriptions of communication because it applies to all time scales. Assessment and management are not synonymous with "receiver" and "sender" because, rather than implying that communication is a series of dyadic frames, $A / M$ is about the interplay between these roles and the regulatory processes they underlie. A/M is based upon evolutionary theory, rather than analogies to human communication, and it highlights regulatory processes for the proximate time frame. Thus, by "sounding big" anurans depicted their size, assessors reacted according to their own evaluations, and communication accomplished what, otherwise, would have resulted from fighting. Male frogs regulated or managed the behavior of smaller males and females using communication.

\section{MOTIVATION-STRUCTURAL RULES IN CLOSE RANGE COMMUNICATION}

The anuran vocalizations that depict size also illustrate how pitch became associated with motivation in warm-blooded vertebrates. Birds and mammals, as endothermic, have high metabolism that increases the cost of large size, so it is no accident that they stop growing at sexual maturity and are similar in size. Aggressive birds and mammals still use deep sounds as a symbol of large size to communicate threat. The sounds used by aggressive birds and mammals are low in frequency, whereas fearful or appeasing individuals use high-frequency sounds. We are able to appreciate the underlying motivation because humans use vocal intonations expressing aggression or appeasement in the same general way (Ohala 1980, 1984).

The relation between pitch and sound quality has been described as motivationstructural rules (M-S rules) (Morton 1977). M-S rules, as depicted in Fig. 1 describe the relation between the physical form of a vocalization and its underlying motivation. Owings \& Morton (1998) discuss this model at length.

The model provides a source of hypotheses about a vocalization's function that is based upon its form. For example, a call in the center of Fig. 1 tends towards neither the low, harsh endpoint nor the high, tonal endpoint. In fact, its form is ambivalent and tends towards both endpoints through its rising and falling in frequency. The prediction from Fig. 1 is that the caller is neither fearful nor aggressive. If the call is in its repertoire, then one needs to describe the 

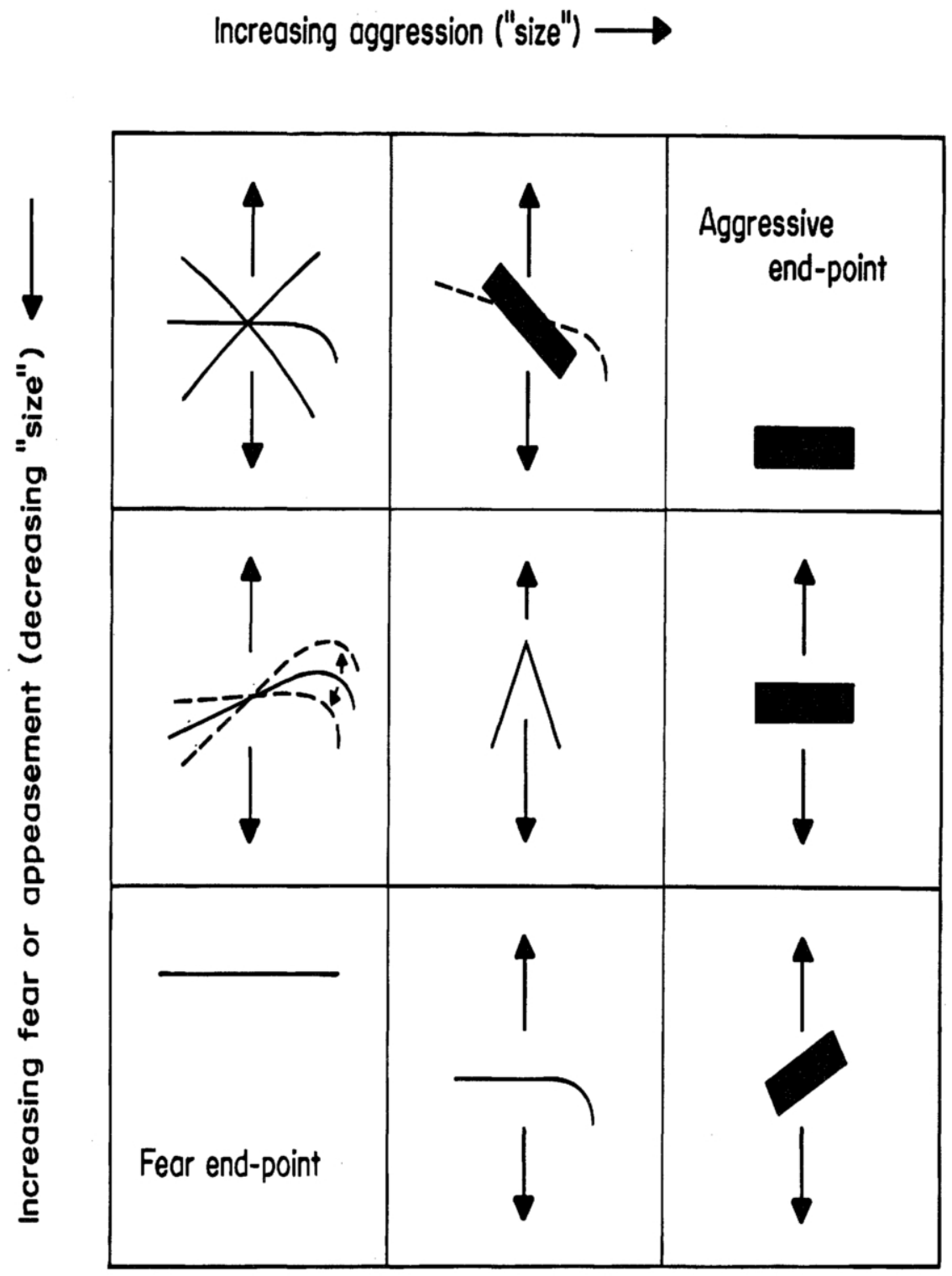

Fig. 1. A diagrammatic representation of vocal forms to illustrate the motivation-structural code. Each figure shows a hypothetical sound spectrogram: thin lines mean a tone or whistlelike sound, and thick lines harsh or broad-band sounds. The vocal forms grade from high pitched and tonal (fear endpoint) to low pitched and harsh (aggressive endpoint). In the upper left figure, motivation is weakly tending toward aggression if the thin line slopes downwards (its pitch drops towards the aggressive endpoint), and toward fear if the line slopes upwards. In the center left vocal form, closer to the fear endpoint, vocalizations rise variously upwards and are all tonal. The three figures on the right (aggressive) side of the diagram are all broad band, but the pitch is rising in the 'distress' call (lower right corner), where fear and aggression are evoked with equal strength. The central form depicts a chevron (the 'bark') because motivation and vocal form are squarely between the endpoints and therefore the form both rises and falls in pitch. 

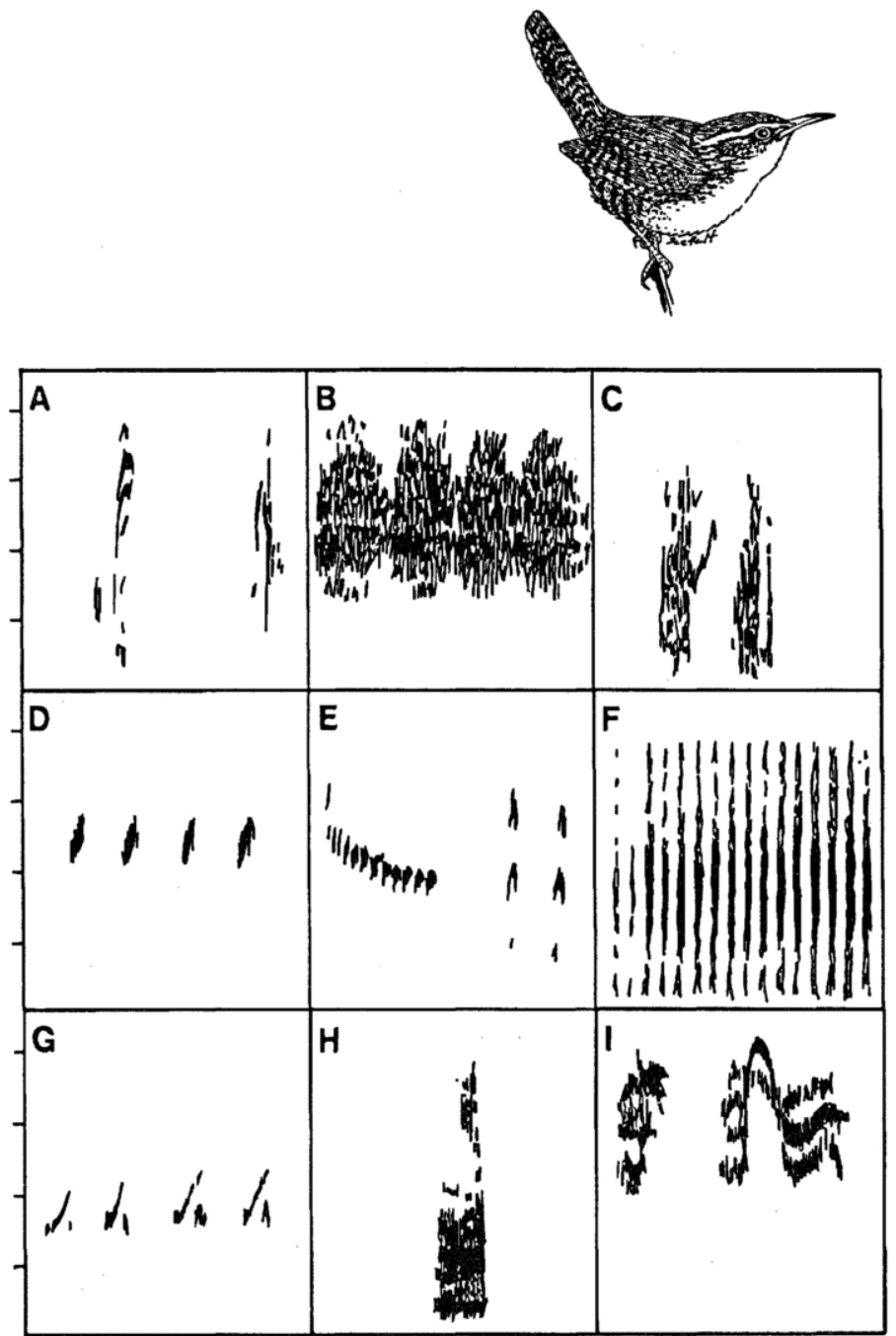

Fig. 2. The Carolina Wren (Thryothrous ludovicianus) and its vocalizations inserted into the motivation-structure code matrix (Fig. 1) to show the close fit. Note the tonal qualities of squares A-G and the increasingly lower pitch and harshness as you move right and up. The endpoints are the growl (C) and pees (G), although those depicted are not as high pitched as this vocalization can become. The pi-zeet (A) to rasp (B) to growl (C) function to keep close together with mate or fledged brood mates, mob ground predators, and attack conspecifics, respectively. The barks (E) show the male cheer, a series of chevrons and the female dit, both given whenever anything of interest is perceived but when neither attack nor fleeing is likely. Females only produce nyerk $(\mathrm{H})$ and chatter $(\mathrm{F})$. Both sexes produce scees (I) when loosing a fight. Chirts are illustrated in D. Morton \& Shalter (1977) describe their use in predator surveillance. See Table 1 for further illustrations of this species vocal repertoire.

contexts in which the call occurs and then perform experiments to induce the call. We know from observations and experiments that such chevron-shaped calls are verycom- monly used in mobbing, for example. In mobbing, something of importance is perceived but it will not be attacked or escaped from. A barking domestic dog uses the 
Table 1. Vocalizations of the Carolina wren (Thryothorus ludovicianus) arranged in order of decreasing distance between communicants.

\begin{tabular}{lll}
\hline Vocalizations & Distance between Communicants & Acoustic structure/variation \\
\hline Male song & Long & Tonal/none \\
Male cheer & Long to medium & Tonal/none \\
Female chatter & Medium to short & Harsh/little \\
Female dit & Medium to short & Tonal/little \\
Rasp & Short & Harsh/great \\
Chirt & Short to medium & Tonal to harsh/great \\
Pi-zeet & Short & Tonal to harsh/great \\
Male tsuck & Short & Tonal/little \\
Female nyerk & Short & Harsh/moderate \\
Scee & Short & Tonal to harsh/great \\
Pee & Short & Tonal to harsh/great \\
Growl & Short & Harsh/little \\
\hline
\end{tabular}

chevron-shaped calls in much the same way as birds do.

The operation of M-s rules can be illustrated by the Carolina Wren (Thryothorus ludovicianus) (Fig. 2), a native of southeastern North America and parts of Mexico and Guatemala. Wrens have twelve vocalization types many of which grade considerably within and between vocal types. Gradation is particularly common in the calls used by birds close to one another (Table 1). When these are placed in the M-s rules model, they conform generally to the predictions associating vocal structure with motivation (Fig. 2). Variations within a vocal category also fit the M-s rules model as well as do the major categories as depicted in Table 1 (Owings \& Morton 1998).

\section{RANGING: THE AVIAN PERCEPTION OF DISTANCE}

Ranging is a perceptual mechanism whereupon a bird measures the amount of degradation in a signal through matching it with the same signal stored in its memory. The bird perceives the apparent distance to the vocalizer because degradation increases with distance (Morton 1986). Ranging is performed by listeners it is assessment, and, as such, has profound effects upon managers and the evolution of their vocalizing. Some of these effects will be outlined below.

Ranging is usually discussed in relation to long distance communication but it is by no means restricted to long distances. It is sometimes equated with the "acoustic adaptation hypothesis" (Rothstein \& Fleischer 1987) wherein songs, especially dialects or song neighborhoods (Payne et al. 1988) arise because some song characteristics propagate better than others in specific habitats. While there is little doubt that ranging can bring about acoustic adaptation in general features of songs (Gish \& Morton 1981, Brown \& Hanford 1996, Morton 1996), the finer features of song that define dialects are not likely adaptations to habitat acoustics. This is because the act of ranging by assessors does not concern only acoustic adaptation of the songs they are listening to. It is most important for ranging that the listener 
share the vocalization with the singer. Listeners that hear a signal that is also in their memory can estimate their distance to the vocalizer and make adaptive responses. Those listeners that do not have the received signal in memory are more likely to interrupt their activities to investigate the signal's origin.

The correlation we found between frequency-dependent attenuation and frequencies of forest birds' songs in Panama was due to the high acoustic homogeneity of these tropical forests (Morton 1975, 1986). Panamanian forest birds used songs with a fundamental frequency near $2200 \mathrm{~Hz}$, the frequency shown to propagate best. But this finding should not be generalized because, in Panamanian forests, the distance from its source to which a song is detectable and the distance at which degradation lowers its effectiveness are very similar. In most habitats, the frequency characteristics of songs are only loosely affected by habitat acoustics and it is the sharing of songs that affects ranging.

Memorized song sharing is especially important to ranging in populations having dialects. Dialects usually arise in stable neighborhoods wherein the locations of territorial boundaries are known to most of the individuals (Morton 1986). Here, song is probably more effective as a threat or management tool to repulse an intruder if a target individual has the song in its memory. Thus, it is not likely that the specific components of songs that researchers use to distinguish one dialect from another will be a result of habitat acoustics. At the same time, dialect differences are not simply cultural differences with no biological significance (e.g., Mundinger 1980, Lynch \& Baker 1993). The biological significance arises from the more efficient defense of territories afforded managers that allow assessors proper distance cues. The proper distance cues, perceived by assessors through ranging, are more threatening and, therefore, effectively replace the singer's need to fight and chase intruders.

Bellicose whispers. - Whisper song or "quiet song" illustrates nicely the results of ranging over short distances. Songs of passerine birds are usually delivered at high amplitude. Under certain circumstances, however, the amplitude of these songs are reduced. These "whisper songs" or "quiet songs" have not been well studied. Here, we present an idea we feel provides a functional explanation for the use and evolution of whisper singing based upon ranging theory. This idea is an alternative to one by Dabelsteen et al. (1998), who predicted that these vocalizations are designed to be unobtrusive so as to avoid detection by predators or attracting neighboring males intent on extrapair copulations. Furthermore, they suggested that whisper songs would be used during maximum vocal activity in the local population and during the breeding season.

Reduced amplitude produces two results. First, the song attenuates to masking level at shorter distances from the singer than do songs with higher source amplitude. Second, and most important to the evolution of whisper song, reducing source amplitude also reduces the amount of energy reaching listeners by indirect pathways, e.g., through reverberation, when sender and receiver are close together. By definition, sound reaching the ear by reverberation has traveled farther than sound traveling straight from singer to listener. This is seen in the longer time it takes reverberated sound to reach the listener's ear. Also, reverberations lose more energy than direct sound because their propagation paths are longer and energy is dissipated when they interact with reverberative boundaries such as tree trunks. One consequence: in a signal with low source amplitude direct sound energy will predominate 
when sender and receiver are relatively close. In contrast, a loud song in this situation would generate echoes from boundaries at longer distances than would one with low source amplitude. One must yell to get an echo from a far boundary.

Whisper songs, therefore, may be thought of as non-reverberative songs as well as songs of low source amplitude. What are the conditions under which these songs should function to manage the behavior of recipients effectively and how do they accomplish this? Ranging theory combined with the A /M concept of communication provide possible insight. Whisper singing is a means to avoid reverberation so as to enhance the appearance that the singer is close and threatening to an intruder.

While ranging, assessors use their perception of the amount of degradation in a signal to estimate their distance from a calling individual. The perceptual process and its evolutionary consequences for both singers and listeners has been discussed (Morton 1986) and tested (summarized in Owings \& Morton 1998). The findings support the general statement that assessors find degraded signals to be less threatening to their interests than less degraded ones, regardless of perceived amplitude (but see Naguib 1997). A list of species where whisper song has been observed is found in Table 2 .

The first response to song play back in many species of songbirds is to fly, quietly but energetically, searching for the intruder. When birds resume singing, this first song is often whisper song, produced during active searching for the intruder. Whisper song gradually reverts to normal amplitude song over a period of a minute or less.

In Panama, the Green Shrike-vireo Vireolanius pulchellus sings a monotonous song of three whistles peu peu peu, tirelessly. The bird does not leave the canopy of tropical forest and, although not uncommon, is thus rarely seen. The song is extremely loud and birds can be heard by human observers for several hundred meters. Birds become quiet when their song is played back to them and, twice, I witnessed the birds leave the canopy to approach the sound, emanating from a tape recorder at my hip. Each bird, within full view at eye level, began to whisper sing while still searching for the source of the playback. Whisper song, in this case, was remarkably faint compared to the bird's usual shouting.

The shrike-vireo was typical of vireos and other birds that whisper sing in defense of territories. Playback of conspecific song stimulates an aggressive attack response. The intruder is, of course, not discovered by the territory owner, which then searches quietly and then resumes singing after a period of time. These first songs are whisper songs. Whisper songs appear to be entirely aggressive in nature, directed specifically to a rival close at hand but not observed. Tropical Yellow-backed Orioles (Icterus chrysater) respond in the same way as shrike-vireos do. But, in this duetting species, one can obtain whisper song responses from both males and females. Furthermore, whisper song is produced by shrike-vireos and orioles regardless of their breeding status (contra Dabelsteen et al.), because they defend yearlong territories.

The subfamily parulinae contains many species that whisper sing. As with vireos, whisper song is given by birds resuming to sing following silent aggressive responses to playbacks. We observed unprovoked whisper singing in the Hooded Warbler (Wilsonia citrina) during its breeding season in Pennsylvania, USA. A normal accented ending song is wheeta wheeta wheeta wheet TEE o. On six occasions, we observed a male singing normal loud song to suddenly drop the loud accented ending of the song and sing the wheeta syllables very softly. The 
Table 2. Species of New World passerines known to whisper sing.

\begin{tabular}{|c|c|c|}
\hline \multicolumn{3}{|l|}{ Corvidae } \\
\hline Corvus brachyrhynchos & Common Crow & Brown, 1985 \\
\hline Cyanocitta cristata & Blue Jay & pers. obs. \\
\hline \multicolumn{3}{|l|}{ Mimidae } \\
\hline Dumetella carolinensis & Gray Catbird & pers. obs. \\
\hline Mimus polyglottus & Northern Mockingbird & pers. obs. \\
\hline \multicolumn{3}{|l|}{ Turdinae } \\
\hline Turdus grayi ${ }^{*}$ & Clay-colored Robin & pers. obs. \\
\hline Turdus migratorius* & American Robin & pers. obs. \\
\hline Hylocichla mustelina* & Wood Thrush & pers. obs. \\
\hline Catharus minimus & Grey-cheeked Thrush & pers. obs. \\
\hline Catharus fuscater & Slaty-backed Nightingale-thrush & pers. obs. \\
\hline \multicolumn{3}{|l|}{ Sylviinae } \\
\hline Polioptila plumbea* & Tropical Gnatcatcher & pers. obs. \\
\hline Ramphocaenus rufiventris ${ }^{*}$ & Long-billed Gnatwren & pers. obs. \\
\hline \multicolumn{3}{|l|}{ Vireonidae } \\
\hline Vireolanius pulchellus* & Green Shrike-vireo & pers. obs. \\
\hline Vireo olivaceus* & Red-eyed Vireo & pers. obs. \\
\hline Vireo flavoviridis* & Yellow-green Vireo & pers. obs. \\
\hline Hylophilus flavipes* & Scrub Greenlet & pers. obs. \\
\hline \multicolumn{3}{|l|}{ Parulinae } \\
\hline Wilsonia citrina & Hooded Warbler & pers. obs. \\
\hline Oporornis formosus* & Kentucky Warbler & Morton \& Young, 1986. \\
\hline Seiurus aurocapillus* & Ovenbird & pers. obs. \\
\hline Dendroica petechia* & Yellow Warbler & pers. obs. \\
\hline Dendroica pensylvanica* & Chestnut-sided Warbler & pers. obs. \\
\hline \multicolumn{3}{|l|}{ Icterinae } \\
\hline Icterus chrysater* & Yellow-backed Oriole & pers. obs. \\
\hline Icterus galbula* & Northern Oriole & pers. obs. \\
\hline \multicolumn{3}{|l|}{ Fringillinae } \\
\hline Pheucticus ludovicianus* & Rose-breasted Grosbeak & pers. obs. \\
\hline Passerina cyanea* ${ }^{*}$ & Indigo Bunting & pers. obs. \\
\hline
\end{tabular}

* Whisper song by territy owner following playback of song.

males had been singing from their normal locations in the lower limbs of forest trees and had spotted silent intruder males approaching their mates. These females, foraging near the ground, were producing loud chip calls, a call they use to announce their fertile status to males in surrounding territories as well as to their own mate (Stutch- bury \& Neudorf 1998). Whisper singing continued for 1-3 min, then ceased as the owners attacked. The intruder males, some of them being radio-tracked, were from neighboring territories (Stutchbury 1998).

The low amplitude of whisper song produces a semblance to a non-threatening, perhaps even frightened, individual, when com- 
pared to one singing loud regular song. This makes the predictions from ranging theory even more interesting as an example of how insight into an animal's Umwelt (von Uexküll 1909) may lead to advances in our understanding of behavior. Each animal has its own Umwelt, including humans, characteristics of which are determined largely by the animal's sensory mechanisms. Birds, for example, are not notable for their ability to discriminate sound frequencies, but they are notable for their ability to distinguish small time intervals. Ranging theory offers an explanation for this ability: birds detect reverberation and other forms of degradation, and use this to compare incoming sounds to undegraded versions of the same sounds stored in memory. Their sense of time discrimination permits them to hear echoes coming from tree trunks that are "invisible" to us. The Umwelt of a bird, therefore, is quite different from ours in this regard and recognition of this is important to our understanding of their use of whisper song as well as ranging in general.

Whisper song helps manage behavior in two main contexts, aggression and sexual behavior (Dabelsteen et al. 1998). The common thread linking the use of whisper song to these contexts is the assessment provided by nonreverberated sounds that the caller is very close at hand. Quiet song in sexual behavior is usual only in one subfamily of passerines, the thrushes (Turdinae) and in these cases, the song is often of higher frequency than those used in normal loud singing.

The most common context in which whisper song is observed is during territorial aggression. Whisper song is observed most commonly after a playback session when the "intruder" is a taped recording and remains unseen by the defender. Most examples of whisper song derive from territorial defense against a close opponent where threat by sounding close is of obvious benefit (Table 2).

In summary, both M-s rules and ranging theory can provide avenues to research into the function and evolution of avian communication. Both emphasize the strong relationship between function and structure.

\section{LITERATURE CITED}

Brown, T. J. \& Hanford, P., 1998. Acoustic signal amplitude patterns: a computer simulation investigation of the acoustic adaptation hypothesis. Condor 98: 608-623.

Dabelsteen, T., McGregor, P. K., Lampe, H. M., Langmore, N. E. \& Holland, J., 1998. Quiet song in birds: an overlooked phenomonon. Bioacoustics 9: 89-105.

Davies, N. B. \& Halliday, T. R., 1978. Deep croaks and fighting assessment in toads, Bufo bufo. Nature 274: 683-685

Gish, S. L. \& Morton, E. S., 1981. Structural adaptations to local habitat acoustics in Carolina Wren songs. Z. Tierpsychol. 58: 74-84.

Lynch, A. \& Baker, A. J., 1993. A population memetics approach to Chaffinch song evolution: meme diversity within populations. Am. Natural. 141: 597-620.

Morton, E. S., 1975. Ecological sources of selection on avian sounds. Am. Natural. 109: 17-34.

Morton, E. S., 1977. On the occurrence and significance of motivation-structural rules in some bird and mammal sounds. Am. Natural. 111: 855-869.

Morton, E. S., 1986. Predictions from the ranging hypothesis for the evolution of long distance signals in birds. Behaviour 99: 65-86.

Morton, E. S., 1996. Why songbirds learn songs: an arms race over ranging? Poul. Avian Biol. Rev. 7: 65-71.

Morton, E. S. \& Shalter, M. D., 1977. Vocal response to predators in pair-bonded Carolina Wrens. Condor 79: 222-227.

Morton, E. S. \& Young, K., 1986. A previously undescribed method of song matching in a species with a single song "type", the Kentucky Warbler (Oporornis formosus). Ethology 73: 334-342.

Mundinger, P. C., 1980. Animal cultures and a 
general theory of cultural evolution. Ethol. Sociobiol. 1: 183-223.

Naguib, M., 1997. Use of song amplitude for ranging in Carolina Wrens (Thryothorus ludovicianus). Ethology 103: 723-731.

Ohala, J. J., 1980. The acoustic origin of the smile. J. Acoust. Soc. Am. 68: 33.

Ohala, J. J., 1984. An ethological perspective on common cross-language utilization of $\mathrm{F} 0$ of voice. Phonetica 41: 1-16.

Owings, D. H. \& Morton, E. S. 1998. Animal Vocal Communication: a New Approach. Cambridge University Press, Cambridge.

Payne, R. B., Payne, L. L. \& Doehlert, S. M., 1988. Biological and cultural success of song memes in Indigo Buntings. Ecology 69: 104-117.

Rothstein, S. I. \& Fleischer, R. C., 1987. Vocal dialects and their possible relation to honest status signalling in the Brown-headed Cowbird. Condor 89: 1-23.

Ryan, M. J. \& Rand, A. S., 1993. Species recognition and sexual selection as a unitary problem in animal communication. Evolution 47: 647-657.

Stutchbury, B. J. M., 1998. Extra-pair mating effort of male Hooded Warblers. Anim. Behav. 53: 553-561.

Stutchbury, B. J. M. \& Neudorf, D., 1998. Female control, breeding synchrony and the evolution of extra-pair mating strategies. Parker, P \& Burley, N. (eds.) Avian reproductive tactics: female and male perspectives: 103-122 A O U Monograph No. 49, American Ornithologists Union, Washington.

Uexküll, J. v., 1909. Umwelt und innenwelt der Tier. Springer-Verlag, Berlin.

(Received 5 January 2000; Accepted 13 June 2000) 
和文抄録 Japanese Summary of Papers in English

\section{進化から見た鳥類の音声コミュニケーションの起源と機能}

(An Evolutionary View of the Origins and

Functions of Avian Vocal Comunication. 49: 69-78)

$$
\text { ユージン・S・モートン }
$$

\section{スミソニアン研究所 国立動物園}

Conservation and Reserch Center, National Zoological Park, Smithsonian Institution, 1500 Remount Road, Front Royal VA, 22630, USA

コミュニケーションは資源を巡る競争において闘争 の代わりをつとめる. コミュニケーションは直接鉢合 わせになってしまう危険が無いように他の動物の行動 を制御する.メスはつがいの相手になるオスの資質を 見定めるためにコミュニケーションを用いる，このよ うに, 性選択はコミュニケーションに大きく影響を受 けている.

音声コミュニケーションの起源は, 最初の陸上動物 である両生類に今であ見られる. カエルは鳥類や哺乳 類と違って, 性成熟に達した後も体の成長が続く. 大 きな個体は小さな個体よりも低い鳴き声を発すること ができ, 闘争すれば強い. 両生類では低い鳴き声は他 のオスに対しては威嚇的であり，メスにとっては魅力 的である. 重要なことは, 発声のための身体的な構造 と音声の持つ機能とが直接的に関連していることであ る. 音声の機能と発声の機構との関連は, 人間の言葉 のように任意なものではない.

鳥類での体の大きさと鳴き声の音程との関係は, ど のようにして証明されるのだろうか. 体の大きさと音 程との関係はより象徴的であり, さえずりを行う鳥の 動機を最む良く説明している．鳥は攻撃的なときには 低く耳障りな発声を, 争いを鎮めようとしたり，おそ れているときには高く調子を持った発声を行う。この
体の大きさと鳴き声の音程との関係は動機一構造規則 モデルと言われる. このモデルは大きさの象徴的意味 と動機とを関係づけるとともに，体の大きさと闘争能 力という基本的な関係から導き出される. この動機一 構造規則モデルは, 発生機構の身体的形態と機能との 関係を実験するための仮説を立てるのに便利である.

ほとんどの鳥の歌のように, 長距離のコミュニケー ションに用いられる発声は別の問題である, この場合 は通常, 近くの相手に対する発声ほどには動機は重要 ではない. 私は, 鳥たちが互いの距離をどのように測っ ているかを説明するために「伝達距離理論」を創り出 した. 音と音との間の非常に短い時間の間隔を分析す る鳥の能力は, 音の減衰を知覚するのに役立っている. この減衰とは, 歌い手から歌が伝播して来ることによっ て起こる反響などの変化ではなく, 音が球状に広がる ことによって起こる周波数や振幅の成分変化のことで ある. 彼らは聞こえてきた歌と自分の記憶にある歌と を比較することによって，その音がどの位遠くから伝 わってきたかを判断することができる，伝達距離理論 は方言や歌のレパートリー, 歌の複雑さと同様に, い くつかのグループで歌の学習がなぜ進化したのかを説 明する助けになる. 